\title{
Školska klima i sukobi u školi
}

\section{Saša Puzić}

Institut za društvena istraživanja u Zagrebu puzic@idi.hr

\author{
Branislava Baranović \\ Institut za društvena istraživanja u Zagrebu \\ baranov@idi.hr
}

\section{Karin Doolan}

\author{
Odjel za Sociologiju, Sveučilište u Zadru \\ kdoolan@unizd.hr
}

\begin{abstract}
SAŽETAK Promatrajući sukobe među učenicima iz ekološko-razvojne perspektive u tekstu se prezentiraju rezultati istraživanja učeničke, nastavničke i ravnateljske percepcije školske klime vezano uz pojavu i rješavanje sukoba među učenicima. Istraživanje je provedeno na uzorku 370 učenika osmih razreda deset zagrebačkih osnovnih škola, 29 nastavnika i 5 ravnatelja. U istraživanju su korištene mješovite metode istraživanja: anketno ispitivanje učenika, fokus grupe s nastavnicima i intervjui s ravnateljima. Podaci upućuju da su među učenicima najčešći verbalni konflikti, ali znatan broj učenika navodi i fizičke sukobe. Uz konfliktne, u školama postoje i suradnički odnosi među učenicima. Kada je riječ o odnosima s nastavnicima, učenici ih percipiraju kao osobe od kojih se može dobiti podrška u rješavanju sukoba, no istodobno nižim vrijednostima procjenjuju njihovo poštovanje i uvažavanje učenika. Utvrđeno je također da su djevojčice "osjetljivije" od dječaka na pojavu nasilja u školi, te da učenici s najvišim ocjenama i oni koji su rjeđe bili izloženi nasilju nešto pozitivnije procjenjuju školsko okruženje od ostalih učenika.
\end{abstract}

U razgovorima s nastavnicima i ravnateljima blaži se oblici sukoba među učenicima predstavljaju kao sastavni dio školske svakodnevice. Više je nastavnika i ravnatelja izrazilo zabrinutost uslijed pojave "cyber-bullyinga", odnosno verbalnog nasilja preko Facebook-a. Među čimbenicima koji negativno utječu na školsku klimu i pojavu sukoba ističu se nedovoljna stručna osposobljenost nastavnika za rješavanje sukoba među učenicima, ograničavajuće organizacijske karakteristike škole, zdravstvene poteškoće učenika i nesređene obiteljske prilike učenika.

Ključne riječi: školska klima, ekološko-razvojna perspektiva, sukobi i nasilje u školi, odnosi među učenicima, odnosi s nastavnicima, učenička perspektiva, perspektiva nastavnika i ravnatelja 


\section{Uvod}

Istraživanja pokazuju da dugotrajna izloženost nasilnim oblicima ponašanja u školi povećava vjerojatnost socijalne izolacije, depresije, i frustracije među učenicima, što u krajnjoj konzekvenci može dovesti do napuštanja škole i/ili odustajanja od daljnjeg školovanja (Lindstrom Johnson, 2009.). S druge strane, nasilje u školi utječe također i na kvalitetu nastavnog procesa budući da nastavnici zbog rješavanja sukoba i ovladavanja nasilnim situacijama ne mogu dovoljno vremena posvetiti samom poučavanju. Kada je riječ o Hrvatskoj, svjedoci smo sve učestalijeg medijskog izvještavanja o nasilju u školama gdje se prvenstveno govori o ekstremnim oblicima fizičkog i/ili verbalnog zlostavljanja među učenicima (npr. Večernji list, 5. 10. 2011.; Jutarnji list, 20. 10. 2011.). ${ }^{1}$ Iako ovi primjeri ukazuju na to da je nasilje prisutno u školama, istodobno ne postoje sustavna istraživanja o ovome problemu (Buljan Flander, Durman Marjanović i Ćorić Špoljar, 2005.; Bouillet, Uzelac i Kapac, 2005.; Zloković i Bilić, 2006.).

Među razmjerno malobrojnim istraživanjima nasilnog ponašanja u hrvatskim školama reprezentativnim se mogu smatrati rezultati istraživanja koje je 2004. provedeno u organizaciji UNICEF-ovog ureda za Hrvatsku na 23.342 učenika osnovnih škola (Pregrad, 2011.). Prema rezultatima ovoga istraživanja oko 33\% učenika osnovnih škola bilo je izloženo nekom obliku nasilja, od čega je 22,3\% izjavilo da su doživjeli nasilje jedan do dva puta "u zadnjih nekoliko mjeseci", dok je 10,4\% učenika u vrijeme istraživanja bilo izloženo nasilnom ponašanju "2-3 puta mjesečno ili više". Pritom su najčešći oblici nasilja u školi bili nazivanje pogrdnim imenima, ismijavanje i zadirkivanje. Također se ističe podatak da svega 58,7\% osnovnoškolaca nikad nije bilo izloženo ovim vrstama nasilja (Pregrad, 2011.).

Navedene podatke o raširenosti nasilja u hrvatskim školama podupiru rezultati istraživanja koje je 2003. godine provela Poliklinika za zaštitu djece grada Zagreba na 4.904 učenika osnovnih škola u Republici Hrvatskoj, a prema kojemu čak 27\% ispitanih učenika izjavljuje da skoro svakodnevno doživljava neki oblik nasilja u školi (Karlović, 2006.). Iste je godine (šk. god. 2003/2004.) provedeno i istraživanje nastavničkih procjena nasilja u školi na uzorku od 530 razrednika osnovnih i 315 razrednika srednjih škola (Bouillet i sur., 2005.). Polazeći od pretpostavke da su razrednici najinformiraniji o opsegu i karakteristikama nasilnog ponašanja u školi (Bouillet i sur., 2005.) ističe se da 43,1\% razrednika prosuđuje da je u njihovom razredu barem jedan učenik koji se ponaša nasilnički. Pritom 21,5\% razrednika procjenjuje da je riječ o učenicima sklonim verbalnom nasilju, dok gotovo jednak broj njih $(22,4 \%)$ ocjenjuje da je među spomenutim učenicima riječ o podjednakoj sklonosti verbalnom i fizičkom nasilju.

1 U Večernjem listu od 5. 10. 2011. izvještava se o slučaju iz Metkovića, gdje su tri učenice osnovne škole fizički napale i ozlijedile druge dvije učenice. Jutarnji list od 20. 10. 2011. opisuj slučaj iz osnovne škole u Ladimirevcima, gdje je na školskom hodniku 14-godišnja učenica napala i istukla 12-godišnju učenicu. 
Premda je problematika istraživanja nasilja u školi u Hrvatskoj još u začecima (Buljan Flander i sur., 2005.), rezultati navedenih i drugih (po opsegu manjih) istraživanja (usp. Šavora, 2003.; Zloković i Bilić, 2006.) ukazuju na razmjere raširenosti nasilnog ponašanja. S tim u vezi važan je podatak iz spomenutog istraživanja nastavničkih procjena nasilja u školi (Bouillet i sur., 2005.) prema kojemu tek 32,2\% razrednika navodi da se u njihovim razrednim odjelima provodi neki od programa prevencije nasilničkog ponašanja. Ovaj podatak dobiva na težini u svjetlu nastavničke procjene kvalitete programa, gdje među ispitanicima prevladava mišljenje da programi prevencije nasilničkog ponašanja "uglavnom ili uopće ne zadovoljavaju" (25,3\% razrednika), dok samo 2,2\% razrednika procjenjuje da neki od postojećih programa "uglavnom zadovoljava" (1,8\%) ili "u potpunosti zadovoljava" (0,4\%). Nalazi UNICEF-ovog istraživanja nasilja u školama pokazuju da čak 65,1\% učitelja u osnovnim školama navodi da se u odnosu na problem nasilničkog ponašanja osjećaju zbunjeno $(24,0 \%)$, ravnodušno $(0,7 \%)$ i bespomoćno (40,4\%) (Pregrad, 2011.). Zaključno se može reći da podaci dostupnih istraživanja o nasilju u školama u Hrvatskoj upućuju, s jedne strane, na značajnu prisutnost nasilnih oblika ponašanja u školama, a s druge na razmjerno nezadovoljavajuće preventivne programe nasilničkog ponašanja (Bouillet i sur., 2005.).

S obzirom na opisanu situaciju u našem smo istraživanju ispitivali oblike sukoba/ nasilja u školi vezano uz njihov školski socijalni/interakcijski kontekst (odnosi među učenicima, odnosi između nastavnika i učenika) gdje se školsko okruženje, odnosno školska klima shvaća kao čimbenik koji može utjecati na smanjivanje ili pogodovanje javljanju nasilnog ponašanja među učenicima.

\section{2. Školska klima i problem nasilja u školi}

Konceptualni okvir za povezivanje školske klime i nasilnog ponašanja učenika u školi osigurava ekološko-razvojna perspektiva ili model u čijem su središtu različiti čimbenici koji utječu na socijalnu participaciju i razvoj vještina učenika potrebnih za uspjeh u školi, na poslu i u društvu općenito (Fraser, 1996.; Holtappels i Meier, 2000.; Khoury-Kassabri i sur., 2004.). Polazište "ekološko-razvojnog modela" jest pretpostavka o nizu kontekstualnih faktora (npr. obiteljsko okruženje, vršnjačke grupe, školski čimbenici, karakteristike lokalne zajednice) koji utječu na socijalizaciju učenika (usp. Fraser, 1996.; Baker, 1998.; Holtappels i Meier, 2000.). Kod toga ekološko-razvojna perspektiva analizira pretpostavke "za pozitivnu socijalnu participaciju te vještine koje promoviraju uspostavu uspješnih socijalnih odnosa s vršnjacima i odraslima koji slijede konvencionalne norme djelovanja" (Fraser, 1996.:348). U tom smislu uloga školske klime u prevenciji nasilnih oblika ponašanja proizlazi iz njenog utjecaja kao socijalizacijskog konteksta u školi koji potencijalno "osigurava pretpostavke za adekvatno razvijanje kognitivnih i socijalnih vještina", a što u konačnici "može smanjiti tendenciju djece da koriste silu za ostvarivanje socijalnih ciljeva” (Khoury-Kassabri, Benbenishty i Astor, 2005.:165; usp. Baker, 1998.).

Iako postoje brojne definicije školske klime, može se reći da je većina njih suglasna u tome da je školska klima na iskustvu zasnovan, multidimenzionalan, relativno 
trajan percepcijski fenomen koji je zajednički članovima određene škole (Koys i DeCotiis, 1991., prema Baranović, Domović i Štibrić, 2006., v. Peterson i Skiba, 2001.; Tableman, 2004.). Spomenuta percepcija ovisi o tome kako pojedinac doživljava okruženje u školi, npr. osjeća li se ugodno u školskom okruženju, je li okruženje suportivno za učenje i poučavanje, je li adekvatno organizirano i sigurno. To znači da, i ovisno o interesima, vrijednostima, motiviranosti i ostalim karakteristikama pojedinca, školska klima može biti percipirana kao poticajna za individualni razvoj i doprinositi konstruktivnom ponašanju i uključivanju pojedinaca u aktivnosti škole ili pak suprotno, kao destimulirajući kontekst koji doprinosi pasivnosti, pružanju otpora i agresivnom ponašanju (Bošnjak, 1997., Holtappels i Meier, 2000.).

Za potpunije razumijevanje utjecaja školske klime na ponašanje učenika u školi korisno je razlikovati pojedine aspekte ovoga odnosa. Holtappels i Meier (2000.) navode obrasce očekivanja, interakcijsku klimu i relacijsku klimu kao tri međusobno povezana socijalizacijska elementa. Obrasci očekivanja u školi mogu pružati raznovrsne mogućnosti za usvajanje poželjnih normi i vrijednosti, ali jednako tako mogu biti obilježeni i rigidnim pravilima, pritiscima za postignućem i otuđujućim nastavnim iskustvima. Interakcijska klima može poticati na sudjelovanje učenika u životu škole kroz zajedničko odlučivanje ili grupne rasprave, no može biti prožeta i hijerarhijskim i autoritativnim stavovima. Relacijsku klimu određuje intenzitet socijalnih veza i kvaliteta socijalnih odnosa u školi. Na relaciji nastavnik - učenici autori ističu važnost povjerenja, razumijevanja i spremnosti za pomoć od strane nastavnika, dok se za kvalitetu odnosa među učenicima ističe važnost socijalne integracije, solidarnosti i grupne kohezije. Opisani socijalizacijski aspekti školske klime u literaturi se još označavaju i pojmom školskog socijalnog okruženja (Lindstrom Johnson, 2009.).

Rezultati brojnih istraživanja potvrđuju utjecaj različitih elemenata školske klime na pojavu nasilnih oblika ponašanja među učenicima. U pregledu empirijski utvrđenih efekata ovoga odnosa Holtappels i Meier (2000.) ističu da pritisak za prilagodbom i negativni socijalni odnosi u školi utječu na devijantno ponašanje u školi, da nezainteresiranost nastavnika i nesudjelovanje učenika u životu škole utječu na pojavu nasilnog ponašanja, te da dosada i averzija prema školi mogu biti povezani s nasiljem i vandalizmom u školi (Fend, 1977.; Niebel i sur., 1993.; Funk, 1995., prema Holtappels i Meier, 2000.). Na osnovu rezultata vlastitog istraživanja Holtappels i Meier (2000.) nadalje navode da škole s manje fizičkog i verbalnog nasilja karakterizira prvenstveno proaktivni angažman nastavnika odnosno pozitivni socijalni odnosi i grupna kohezija učenika. Važnost odnosa na relaciji nastavnik - učenici ističu također Khoury-Kassabri, Benbenishty i Astor (2005.). Autori pritom navode da suportivni i pozitivni odnosi između nastavnika i učenika smanjuju otuđenje učenika, jačaju privrženost školi te povećavaju važnost uloge škole u očima učenika (Khoury-Kassabri i sur., 2005.; usp. Fraser, 1996.). ${ }^{2}$

2 U svome istraživanju različitih čimbenika koji mogu utjecati na pojavu nasilja u školi (obiteljsko i društveno okruženje, školska klima, vrsta i veličina škole) autori potvrđuju važnost 
U pregledu ${ }^{3}$ recentnih međunarodnih istraživanja o utjecaju školskog okruženja na pojavu nasilja u školi Lindstrom Johnson (2009.) ističe činjenicu da svaka od 25 promatranih studija (npr. Stewart, 2003.; Welsh, 2003.; Khoury-Kassabri i sur., 2007., prema Lindstrom Johnson, 2009.) upućuje na to da školsko okruženje utječe na pojavu nasilja u školi. Na temelju usporedbe rezultata različitih istraživanja autorica posebno izdvaja utjecaj sljedećih elemenata školskog socijalnog okruženja: pozitivan odnos s drugim učenicima, pozitivni odnosi između nastavnika i učenika te jasna i dosljedna školska pravila. Autorica ističe da su se odnosi nastavnika i učenika pokazali kao najkonzistentniji prediktor među svim korištenim mjerama socijalnog okruženja, te da je većina studija također pokazala da je nasilje manje prisutno u školama u kojima su učenici osvijestili školska pravila i gdje su aktivno uključeni u proces donošenja odluka. Istodobno se navodi da su se akademska postignuća i sposobnosti učenika pokazali kao razmjerno slabiji prediktori za pojavu nasilja u školi.

Postojeća istraživanja o utjecaju školskog okruženja na pojavu nasilja u školi uključuju pored socijalnog okruženja u školi također i druge faktore kao što su npr. organizacijske karakteristike škole, prvenstveno veličina škole odnosno razreda, te izvanškolske faktore. U potonje se ubrajaju individualne osobine učenika i njihova specifična životna iskustva, obiteljski čimbenici te različiti kontekstualni faktori poput šire socijalne okoline, kulturnih karakteristika ili socio-ekonomskog statusa učenika i njihovih obitelji (Pollard, Hawkins i Arthur, 1999., prema Khoury-Kassabri i sur., 2005.). Istraživanja pokazuju da u određenim okolnostima ovi faktori mogu kod djece utjecati na smanjene mogućnosti za odgovornu socijalnu interakciju i na taj način povećati vjerojatnost za pojavu agresivnih i nasilnih oblika ponašanja (Fraser, 1996.), a koji se, u konačnici, manifestiraju i u školskom kontekstu. Kada je, primjerice, riječ o obiteljskoj interakciji, Fraser (1996.) navodi da nedosljedan roditeljski nadzor, nepostavljanje granica i učestalo kažnjavanje potiču agresivne reakcije kod djece koje se potom dalje razvijaju te utječu na odnose s vršnjacima i odnose u školi (usp. Baker, 1998.). Za usvajanje agresivnih obrazaca ponašanja također su značajni negativni socijalni uvjeti poput odrastanja u siromaštvu i depriviranoj lokalnoj zajednici, ili na individualnoj razini biološki poremećaji koji nega-

školske klime. Rezultati pokazuju da je školska klima koja uključuje jasna i konzistentna pravila ponašanja kao i pozitivne odnose između nastavnika i učenika povezana s manje nasilja u školi. Pritom se ističe da se efekt školske klime pokazuje u obje ispitivane kulture, židovskoj i arapskoj, i kod učenika različitog socioekonomskog statusa. (Khoury-Kassabri i sur., 2005.).

3 Istraživanja utjecaja školske klime na javljanje i oblike nasilja u školama razmjerno su novijeg datuma. U svome pregledu istraživanja koja se bave odnosom školskog okruženja i nasilja u školi Lindstrom Johnson (2009.) navodi da je od 25 analiziranih studija čak 20 objavljeno nakon 2000. Nepostojanje etablirane istraživačke tradicije iz ovoga područja u svjetskim razmjerima vjerojatno dijelom može objasniti činjenicu da su istraživanja školske klime i nasilja u školi u Hrvatskoj do sada također rijetko provođena. Stoga smo odnos školske klime i pojave nasilja u školi konceptualizirali uglavnom na temelju koncepata i istraživanja stranih autora. 
tivno utječu na savladavanje socijalnih vještina i socijalno učenje (npr. neravnoteža seratonina, hiperaktivnost, impulzivnost, poremećaji pažnje) (Fraser, 1996.; Dake, Price i Telljohan, 2003.). Među individualnim čimbenicima povezanim s nasilnim oblicima ponašanja često se ističu i rodne razlike. Prevladavajuće je stajalište da su dječaci u usporedbi s djevojčicama češće počinitelji i žrtve fizičkog nasilja (Dake i sur., 2003.; Khoury-Kassabri i sur., 2004.), dok o razlikama u sklonosti verbalnim i neizravnim oblicima nasilja ne postoji konsenzus (Khoury-Kassabri i sur., 2004.; Buljan Flander i sur., 2007.).

Istraživanje čije rezultate prezentiramo u tekstu nije ispitivalo pojavu nasilja u školi u svoj njezinoj kompleksnosti. Ono je bilo usmjereno prvenstveno na ispitivanje odnosa okruženja u školi tj. školske klime i konflikata među učenicima u školi, ili preciznije, na analizu učeničke, nastavničke i ravnateljske percepcije školske klime vezano uz javljanje i načine rješavanja sukoba među učenicima.

\section{Cilj, problemi i metodologija istraživanja}

Cilj istraživanja je bio ispitati percepciju učenika, nastavnika i ravnatelja o karakteristikama školske klime vezano uz pojavu i rješavanje sukoba među učenicima.

U tu svrhu definirana su sljedeća istraživačka pitanja: 1) kako učenici percipiraju školsku klimu sa stajališta javljanja i načina rješavanja sukoba među učenicima; 2) postoji li značajna razlika u učeničkoj percepciji školske klime s obzirom na spol, školski uspjeh i učestalost doživljenog nasilja u školi; 3) kako nastavnici i ravnatelji doživljavaju školsku klimu vezano uz nasilje i sukobe u školi.

\subsection{Uzorak i postupak istraživanja}

U istraživanju ${ }^{4}$ je sudjelovalo 370 učenika osmih razreda deset zagrebačkih osnovnih škola te 29 nastavnika i 5 ravnatelja. Polazeći od pretpostavke da je obrazovni status roditelja povezan sa socio-ekonomskim statusom i obrazovnim iskustvima učenika (v. Khoury-Kassabri i sur., 2005.) uzorak škola je konstruiran prema zastupljenosti učenika različitog obrazovnog statusa roditelja. Korišten je stratificirani slučajni uzorak škola s različitim stupnjem prosječnog obrazovnog statusa roditelja

\footnotetext{
4 Ovdje prikazani rezultati dio su šireg istraživačkog projekta o mirovnom obrazovanju u osnovnim školama koji je 2010. proveo Institut za društvena istraživanja u Zagrebu - Centar za istraživanje i razvoj obrazovanja u suradnji sa Centrom za mirovne studije, Zagreb. Kao članovi istraživačkog tima IDIZ-a/CERD-a u projektu su sudjelovali: Saša Puzić (voditelj), Branislava Baranović, Karin Doolan, Boris Jokić i Zrinka Ristić Dedić. Opširniji opis projekta i rezultati istraživanja dostupni su u publikaciji "Učiti za mir: Analitička i normativna podloga za uvođenje vrijednosti, sadržaja i metoda mirovnog obrazovanja u formalni obrazovni sustav", Zenzerović Šloser (ur.), Centar za mirovne studije, Zagreb, 2011.
} 
učenika koji pohađaju školu. Okvir uzorka činio je popis 105 osnovnih škola s područja grada Zagreba, na osnovi kojega su odrectena tri stratuma koji se uveliko podudaraju s lokacijskim smještajem škola na području grada Zagreba: škole s iznadprosječnim, prosječnim i ispodprosječnim indeksom obrazovanja roditelja Izračunati prosjeci na razini škola odnosili su se na sljedeće vrijednosti obrazovnog statusa roditelja: 1=nezavršena osnovna škola ili osnovna škola; $2=$ srednja škola; $3=$ viša škola ili fakultet. Broj izabranih škola iz svakog stratuma proporcionalno je odgovarao ukupnom broju škola u svakom stratumu: tri škole s iznadprosječnim, četiri s prosječnim i tri škole s ispodprosječnim indeksom obrazovanja roditelja. Unutar svakog stratuma škole uključene u uzorak određene su slučajnim odabirom korištenjem programa Research Randomizer. U svakoj od deset škola anketirani su učenici osmih razreda, dok su fokus grupe s nastavnicima i intervjui s ravnateljima održani u pet škola osnovnog uzorka u kojima je bilo moguće organizirati intervjue i fokus grupe.

Istraživanje je provedeno u studenom i prosincu 2010. Godine. U istraživanju su korištene mješovite metode istraživanja: anketno ispitivanje, fokus grupe i intervjui. U anketnom ispitivanju unutar svake škole sudjelovali su učenici dva osma razredna odjela za koje su prethodno prikupljeni pristanci roditelja za sudjelovanje u istraživanju. U svakom razredu učenici su upitnik popunjavali grupno jedan školski sat za vrijeme redovne nastave. Anketni upitnik se sastojao od pitanja (varijabli) kojima je ispitivana učenička percepcija različitih aspekata i oblika konfliktnog ponašanja učenika u školi, školskoj klimi (školskog okruženja), te izloženost učenika nasilnim oblicima ponašanja. Upitnikom su također prikupljeni socio-demografski podaci o učenicima kao što su spol i uspjeh u školi koje smo dovodili u vezu s učeničkom percepcijom nasilnog ponašanja učenika u školi. ${ }^{5}$ Za ispitivanje školskog okruženja koristili smo modificiranu skalu za razrednu klimu ${ }^{6}$ konstruiranu u okviru projekta Multisite violence prevention (2004.) (Classroom climate scale opisana u Dahlberg i sur., 2005.). Skalom smo ispitivali tri aspekta školske klime iz perspektive učenika: 1. odnosi među učenicima, 2. odnosi učenika i nastavnika i 3. prijavljivanje sukoba, odnosno nasilja nastavnicima. Skala se sastojala od 18 tvrdnji smještenih na ljestvici Likertovog tipa od 5 stupnjeva pri čemu je 1 značilo da se učenik ili učenica uopće ne slaže s tvrdnjom, a 5 potpuno slaganje.

Kvalitativni dio istraživanja proveden je u pet škola odabranih iz uzorka (prigodni uzorak) u kojima je intervjuirano pet ravnatelja tih škola i održano pet fokus grupa s nastavnicima. U fokus grupama je sudjelovalo ukupno 29 nastavnika, a s ciljem

\footnotetext{
5 Navedene su samo one varijable iz upitnika čije rezultate prezentiramo u tekstu.

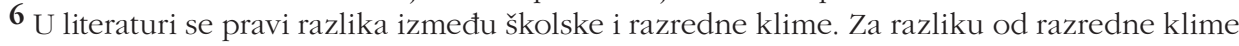
koja uključuje odnose između nastavnika i njihovih učenika ili samo odnose među učenicima u promatranom razredu, školska klima je širi pojam i obuhvaća odnose nastavnika prema drugim nastavnicima, učenicima, administrativnom osoblju i ravnatelju (Domović, 2003.; Bošnjak, 1997.). Mi koristimo termin školska klima, jer se odnosi među učenicima i odnosi nastavnika prema učenicima koje ispitujemo ne mogu reducirati isključivo na situaciju u razredu. Promatramo ih kao element ozračja u školi, odnosno školske klime.
} 
dobivanja dubljeg uvida u istraživački problem nasilja u školama. Protokol za intervjue i fokus grupe sastojao se od otvorenih pitanja organiziranih u tri cjeline: procjena učestalosti i oblika sukoba u školama, mogući čimbenici koji utječu na nasilno ponašanje u školama, te načini rješavanja sukoba u školama. Intervjui s ravnateljima i fokus grupe s nastavnicima trajali su u prosjeku jedan školski sat. Svi su audio materijali transkribirani i potom analizirani u NVivo programu za kvalitativnu obradu podataka. Analiza je provedena tako što su se induktivnim procesom dodjeljivali kodovi odgovorima ravnatelja i nastavnika prema spomenutim cjelinama. Taj je proces rezultirao temama i podtemama kao što su: škole prema učestalosti sukoba (kontinuum vrlo često-vrlo rijetko), oblici sukoba (fizički, verbalni, cyber bullying), te čimbenici koji doprinose (ne)skladnim odnosima u školi (razina škole koja uključuje osposobljenost i autoritet nastavnika, veličinu škole, broj stručnih suradnika, pedagoške mjere; razina pojedinca i zdravstvene poteškoće; razina obitelji i odnosa u njima; širi društveni kontekst i mediji).

\section{Rezultati i rasprava}

\section{1. Školska klima i sukobi u školi: perspektiva učenika}

U operacionalizaciji koncepta školska klima pošli smo od teorijskog stava da interakcijski i relacijski aspekt odnosa među učenicima kao i odnosa između nastavnika i učenika čine središnje aspekte školske klime kada je promatramo sa stajališta pojave sukoba u školi. U tom smislu za razumijevanje problema sukoba/ nasilja u školi važno je istražiti kako učenici percipiraju odnose među učenicima i odnose između učenika i nastavnika u situacijama javljanja i rješavanja sukoba među učenicima u školi. Sukladno tome, u istraživanju smo ispitivali tri aspekta školske klime iz perspektive učenika: 1. odnose među učenicima, 2. odnose učenika i nastavnika i 3. prijavljivanje sukoba, odnosno nasilja nastavnicima. U Tablici 1 prezentirani su deskriptivni pokazatelji i frekvencije odgovora učenika na tvrdnje skale školske klime.

Kada je riječ o učeničkoj percepciji učestalosti pojedinih vrsta sukoba među učenicima, iz podataka (Tablica 1) je vidljivo da je u školama najčešće prisutno ogovaranje (69\% posto učenika se uglavnom i u potpunosti složilo s tvrdnjom da u njihovoj školi učenici ogovaraju jedni druge). Zatim slijedi ismijavanje, pri čemu se, vidno manji, ali još uvijek znatan, broj učenika (54\%) uglavnom i potpuno složio s tvrdnjom da učenici u njihovoj školi ismijavaju jedni druge. Ovi nalazi su u skladu s rezultatima drugih istraživanja provedenih u Hrvatskoj (Pregrad, 2011.) prema kojima u školama također prevladavaju verbalni sukobi, točnije ogovaranje, ismijavanje ili međusobno vrijeđanje. Sudeći prema podacima, fizički sukobi i međusobno isključivanje učenika iz školskih aktivnosti i druženja su manje prisutni u školama, ali su također dio školske svakodnevice. Preciznije, 42\% učenika se uglavnom ili u potpunosti složilo s tvrdnjom da se u njihovoj školi učenici fizički sukobljavaju. Iako je ovaj postotak manji od postotka učenika koji smatraju da u njihovoj školi ima verbalnog nasilja, on se može smatrati velikim jer je riječ o fizičkom nasilju. 
Nešto manji broj učenika (36\%) se složio s tvrdnjom da u njihovoj školi učenici isključuju iz aktivnosti i druženja one koji se razlikuju od ostalih.

Tablica 1.

Deskriptivni pokazatelji i frekvencije odgovora učenika na tvrdnje Skale školske klime

\begin{tabular}{|c|c|c|c|c|}
\hline \multirow[b]{2}{*}{ Tvrdnje } & \multirow[b]{2}{*}{$\mathbf{M}$} & \multirow[b]{2}{*}{ SD } & \multicolumn{2}{|c|}{$\%$} \\
\hline & & & $\begin{array}{l}\text { Uglavnom } \\
\text { se slažem }\end{array}$ & $\begin{array}{l}\text { U potpunosti } \\
\text { se slažem }\end{array}$ \\
\hline 1. Učenici ogovaraju jedni druge & 3,82 & 1,181 & 33,9 & 35,0 \\
\hline $\begin{array}{l}\text { 2. Učenici se mogu slobodno obratiti nastavniku za pomoć } \\
\text { kad imaju neki spor ili sukob s učenicima }\end{array}$ & 3,73 & 1,273 & 27,2 & 36 \\
\hline $\begin{array}{l}\text { 3. U situacijama kad učenici prijave vrijeđanje ili nasilje, } \\
\text { nastavnici se uključuju u rješavanje sukoba ili spora }\end{array}$ & 3,71 & 1,208 & 29,9 & 32,3 \\
\hline $\begin{array}{l}\text { 4. Nastavnici pomažu u rješavanju sukoba i sporova među } \\
\text { učenicima }\end{array}$ & 3,53 & 1,195 & 34,4 & 23,2 \\
\hline 5. Učenici se prijateljski odnose jedni prema drugima & 3,52 & ,985 & 49,7 & 11,1 \\
\hline 6. Učenici ismijavaju i vrijeđaju jedni druge & 3,41 & 1,216 & 33,5 & 20,0 \\
\hline 7. Nastavnici pažljivo slušaju mišljenja učenika & 3,34 & 1,290 & 31,5 & 20,9 \\
\hline $\begin{array}{l}\text { 8. Nastavnici ohrabruju učenike da kažu kad dođe nasilja, } \\
\text { sporova i sukoba }\end{array}$ & 3,31 & 1,457 & 29,2 & 26,0 \\
\hline 9. Učenici se međusobno pomažu u školskim aktivnostima & 3,29 & 1,134 & 35,6 & 13,0 \\
\hline $\begin{array}{l}\text { 10. Učenici različitih stilova života se međusobno dobro } \\
\text { slažu }\end{array}$ & 3,19 & 1,092 & 33,8 & 9,7 \\
\hline 11. Učenici se fizički sukobljavaju & 3,19 & 1,179 & 27,6 & 14,6 \\
\hline $\begin{array}{l}\text { 12. Nastavnici se odnose s poštovanjem i uvažavanjem } \\
\text { prema učenicima }\end{array}$ & 3,15 & 1,278 & 29,2 & 15,5 \\
\hline $\begin{array}{l}\text { 13. Učenici isključuju iz školskih aktivnosti i druženja } \\
\text { učenike koji se razlikuju od ostalih }\end{array}$ & 3,06 & 1,211 & 22,0 & 14,1 \\
\hline 14. Nastavnici se ponašaju pravedno prema učenicima & 2,89 & 1,266 & 24,0 & 10,9 \\
\hline $\begin{array}{l}\text { 15. Tijekom rasprava na nastavi učenici uvažavaju mišljenja } \\
\text { drugih učenika }\end{array}$ & 2,83 & 1,104 & 24,1 & 5,5 \\
\hline $\begin{array}{l}\text { 16. Učenici pažljivo slušaju jedni druge tijekom rasprava na } \\
\text { nastavi }\end{array}$ & 2,54 & 1,151 & 18,8 & 4,4 \\
\hline 17. Nastavnici ismijavaju ili vrijectaju neke učenike & 2,10 & 1,221 & 10,6 & 5,2 \\
\hline 18. Učenici vole biti u školi & 1,92 & 1,100 & 8,4 & 2,2 \\
\hline
\end{tabular}

Na osnovu mišljenja učenika, zaključno se o sukobima među učenicima može reći da su u ispitivanim školama prisutni različiti oblici sukoba pri čemu su najrasprostranjeniji verbalni sukobi (ponajprije ogovaranje). Iako nijedan od spomenutih oblika sukoba nije bezazlen i zanemariv s obzirom na njihove psihičke i fizičke 
posljedice po učenike, naročito je zabrinjavajući nalaz da relativno visok postotak učenika smatra da u njihovim školama ima fizičkih sukoba.

Rezultati pored toga upućuju da odnosi u školi nisu jednoznačni. Naime, spomenuti oblici sukoba, odnosno konfliktni odnosi među učenicima ne isključuju njihove suradničke odnose. U prilog ovakvoj tvrdnji govori podatak da se oko $61 \%$ učenika suglasilo s tvrdnjom da se prijateljski odnose jedni prema drugima, a 49\% s tvrdnjom da međusobno surađuju u školskim aktivnostima.

O karakteristikama socijalnog ozračja škole također govore i podaci o tome kako su percipirani odnosi među učenicima tokom nastave. Podaci u Tablici 1 upućuju da je, kada je riječ o nastavi, postotak pozitivnih odgovora na tvrdnje o međusobnim odnosima manji nego kada je riječ o školskim aktivnostima općenito. Tako se npr. nešto manje od jedne trećine učenika uglavnom i u potpunosti složilo $s$ tvrdnjom da učenici tijekom rasprava uvažavaju mišljenja drugih učenika, dok ih se 23\% uglavnom i potpuno složilo s tvrdnjom da učenici pažljivo slušaju jedni druge tijekom rasprava na nastavi. Potonja dva podatka treba naglasiti jer upućuju na to da relativno mali broj učenika zna pažljivo slušati i uvažavati mišljenja drugih, tim više što je riječ o vještinama koje spadaju u temeljne vještine razvijanja konstruktivnih odnosa i komunikacije među učenicima.

Sa stajališta rješavanja sukoba među učenicima bilo je važno istražiti i odnos nastavnika i učenika, posebno kada je riječ o konfliktnim situacijama. Rezultati u tablici pokazuju da većina ispitanih učenika percipira nastavnike kao osobe od kojih mogu dobiti podršku pri rješavanju sukoba s drugim učenicima. Štoviše, tvrdnje o nastavničkoj podršci pri rješavanju sukoba nalaze se u skupini najviše procijenjenih tvrdnji (od 2. do 4. mjesta na rang ljestvici) pri čemu je podršku nastavnika pozitivno procijenilo više od dvije trećine učenika. Takav nalaz upućuje da veliki broj učenika percipira nastavnike kao osobe od kojih mogu dobiti podršku pri rješavanju sukoba s drugim učenicima. Međutim kada je riječ o učeničkoj percepciji odnosa nastavnika prema učenicima općenito, slika o nastavnicima se mijenja. Konkretnije, postotak učenika koji su suglasni s tvrdnjama da se nastavnici s poštovanjem i uvažavanjem odnose prema učenicima te da se pravedno ponašaju prema učenicima zamjetno je niži nego za prethodne tvrdnje (45\% i 35\%). Relativno mali postotak učenika (35\%) se složio s tvrdnjom da se nastavnici ponašaju pravedno prema učenicima, dok se 16\% učenika uglavnom i u potpunosti složilo s tvrdnjom da nastavnici ismijavaju ili vrijeđaju neke učenike. Potonja dva podatka upućuju da i kod dijela nastavnika treba razvijati socijalne vještine kako bi se poboljšala komunikacija s učenicima i efikasnije prevenirali i rješavali sukobi među učenicima u školi. Na problem nedovoljne osposobljenosti osnovnoškolskih nastavnika za rješavanje konflikata među učenicima ukazala su i druga istraživanja u Hrvatskoj, kao što je na npr. u uvodnom dijelu spomenuto UNICEF-ovo istraživanje (Pregrad, 2011.).

Prikazani rezultati odgovora učenika o interakcijskim i relacijskim aspektima školske klime upućuju da su škole i razredi psihosocijalni sustavi s raznolikim i di- 
namičnim odnosima koji uključuju višeznačne i kompleksne odnose kako među samim učenicima, tako i između nastavnika i učenika.

\subsubsection{Faktorska struktura učeničke percepcije školske klime}

Da bismo dobili potpuniji uvid u učeničku percepciju školske klime proveli smo faktorsku analizu odgovora učenika na pojedine tvrdnje koje opisuju karakteristike školske klime. Rezultati faktorske analize prezentirani u Tablici 2 govore o strukturi međusobne povezanosti odgovora na pojedine tvrdnje, a ekstrahirani se faktori, koji grupiraju međusobno povezane tvrdnje u skupine, mogu smatrati dimenzijama ili aspektima školske klime. Provedena je faktorska analiza glavnih komponenata uz Kaiserov kriterij i varimax rotaciju. Zadržane su tri komponente (faktora) koje su imale karakteristične korijene značajno veće od $1,00(5,03 ; 2,03$ i 1,43). Sve tvrdnje imaju značajna zasićenja s komponentom kojoj pripadaju pri čemu se korelacije kreću od .531 za tvrdnju "učenici se prijateljski odnose jedni prema drugima" do .812 za tvrdnju "učenici ogovaraju jedni druge". Tvrdnja "učenici ismijavaju ili vrijeđaju jedni druge" je ispuštena iz analize jer je imala podjednako značajna zasićenja na dvije komponente. Tri izlučena faktora objašnjavaju ukupno 51,78\% ukupne varijance, što predstavlja dovoljno velik iznos za metodološki korektno zaključivanje o strukturiranosti analiziranih tvrdnji.

Tablica 2.

Faktorska struktura učeničke percepcije školske klime

\begin{tabular}{|l|c|l|}
\hline Faktori & \multicolumn{2}{|c|}{ Tvrdnje } \\
\hline Faktor I. (27,93\% zajedničke varijance) &, 811 & $\begin{array}{l}\text { Nastavnici pomažu u rješavanju sukoba i sporova među } \\
\text { učenicima }\end{array}$ \\
\hline Nastavnička podrška učenicima &, 780 & $\begin{array}{l}\text { Učenici se mogu slobodno obratiti nastavniku za pomoć kad } \\
\text { imaju neki spor ili sukob s učenicima }\end{array}$ \\
\hline &, 749 & Nastavnici pažljivo slušaju mišljenja učenika \\
\hline &, 704 & $\begin{array}{l}\text { U situacijama kad učenici prijave vrijectanje ili nasilje, } \\
\text { nastavnici se uključuju u rješavanje sukoba ili spora }\end{array}$ \\
\hline &, 678 & $\begin{array}{l}\text { Nastavnici se odnose s poštovanjem i uvažavanjem prema } \\
\text { učenicima }\end{array}$ \\
\hline Faktor II. (15,92\% zajedničke varijance) &, 812 & $\begin{array}{l}\text { Nastavnici se ponašaju pravedno prema učenicima } \\
\text { sporova i sukoba }\end{array}$ \\
\hline Konfliktni odnosi među učenicima &, 796 & Učenici ismijavaju i vrijeđaju jedni druge \\
\hline &, 741 & Učenici se fizički sukobljavaju \\
\hline & $\begin{array}{l}\text { Učenici isključuju iz školskih aktivnosti i druženja učenike } \\
\text { koji se razlikuju od ostalih }\end{array}$ \\
\hline
\end{tabular}




\begin{tabular}{|l|c|l|}
\hline Faktori & \multicolumn{2}{|c|}{ Tvrdnje } \\
\hline Faktor III. (7,93\% zajedničke varijance) &, 654 & Učenici vole biti u školi \\
\hline Suradnički odnosi među učenicima &, 618 & $\begin{array}{l}\text { Učenici pažljivo slušaju jedni druge tijekom rasprava na } \\
\text { nastavi }\end{array}$ \\
\hline &, 610 & $\begin{array}{l}\text { Tijekom rasprava na nastavi učenici uvažavaju mišljenja } \\
\text { drugih učenika }\end{array}$ \\
\hline &, 604 & Učenici različitih stilova života se međusobno dobro slažu \\
\hline &, 578 & Učenici se međusobno pomažu u školskim aktivnostima \\
\hline
\end{tabular}

Prvi faktor objašnjava najveći iznos zajedničke varijance i dominantan je faktor. Strukturiran je od sedam tvrdnji čiji se sadržaj odnosi na nastavničku podršku učenicima u konfliktnim situacijama, nastavničko poštovanje i uvažavanje učenika te pravedan odnos nastavnika prema učenicima. Budući da svojim sadržajem izražava spremnost nastavnika da pomognu učenicima u rješavanju sukoba i njihov respekt prema učenicima, ovaj smo faktor nazvali nastaunička podrška učenicima. Drugi faktor sadrži četiri tvrdnje koje svojim sadržajem izražavaju različite vrste konfliktnih odnosa među učenicima: ogovaranje, ismijavanje i vrijeđanje, fizičko sukobljavanje te isključivanje iz školskih aktivnosti i druženja učenika koji se razlikuju od ostalih. Stoga smo ga nazvali konfliktni odnosi među učenicima. Treći faktor u svojoj konfiguraciji sadrži šest tvrdnji koje govore o pozitivnom odnosu učenika prema školi, međusobnom uvažavanju i pomaganju učenika te njihovim prijateljskim odnosima. Kako je suradnja među učenicima zajednička karakteristika svih tvrdnji ovaj smo faktor nazvali suradnički odnosi među učenicima.

Pouzdanost navedenih faktora, određena metodom unutrašnje konzistencije, pokazala se zadovoljavajućom: Cronbachov $\alpha$-koeficijent za faktor nastavnička podrška učenicima iznosi 0,85, za faktor konfliktni odnosi među učenicima 0,81, a za faktor suradnički odnosi među učenicima 0,69. Korelacije među faktorima su statistički značajne ali relativno niske i logične, što upućuje da faktori (subskale) "mjere" različite dimenzije istog konstrukta - školske klime. Između faktora nastavnička podrška učenicima i faktora konfliktni odnosi među učenicima $\mathrm{r}=-.21$, između faktora nastavnička podrška učenicima i suradnički odnosi među učenicima $\mathrm{r}=.24$, a između faktora konfliktni odnosi među učenicima i suradnički odnosi među učenicima $\mathrm{r}=-.49$.

Srednje vrijednosti učeničkih procjena za pojedine faktore upućuju da su sve tri dimenzije školske klime procijenjene osrednje, tj. srednje vrijednosti procjena u svim trima dimenzijama nalaze se u sredini skale. ${ }^{7}$ Pritom je najviše procijenjena

7 Nastavnička podrška učenicima: $\mathrm{M}=3,46 ; \mathrm{SD}=$ 0,894; Konfliktni odnosi među učenicima: $\mathrm{M}=3,37 ; \mathrm{SD}=0,961 ;$ Suradnički odnosi među učenicima: $\mathrm{M}=2,88 ; \mathrm{SD}=0,688$ 
dimenzija nastavnička podrška učenicima čija procjena tendira prema pozitivnom polu skale ("uglavnom se slažem").

Zaključno se može reći da iz navedene faktorske strukture tvrdnji proizlazi da učenici u istraživanim školama percipiraju školsku klimu višeznačno, tj. kao ozračje koje ima različite pa i međusobno suprotstavljene aspekte ili dimenzije, kao što su npr. konfliktni i suradnički odnosi među učenicima. Ohrabrujući je podatak da su učenici pritom najvišim skalnim vrijednostima procijenili dimenziju koja govori o nastavničkoj podršci učenicima.

\subsubsection{Razlike u percepciji školske klime}

Za razumijevanje učeničke percepcije školske klime važno je istražiti razlike u percepciji školske klime obzirom na individualna obilježja učenika. Da bismo ustanovili postoje li razlike u učeničkoj percepciji školske klime testirali smo statističku značajnost razlika u prosječnim procjenama učenika s obzirom na njihov spol, školski uspjeh te učestalost doživljenog nasilja u školi ili agresivnost škole.

Rezultati testiranja značajnosti razlika prema spolu (Tablica 3) pokazuju da postoje statistički značajne razlike između učenika i učenica u percepciji školske klime na tri tvrdnje.

Tablica 3

Razlike u učeničkoj percepciji školske klime prema spolu učenika

\begin{tabular}{|l|c|c|c|c|c|c|c|}
\hline \multirow{2}{*}{ Tvrdnje } & \multicolumn{2}{|c|}{ Učenice } & \multicolumn{2}{c|}{ Učenici } & & & \\
\cline { 2 - 8 } & M & SD & M & SD & t & df & P \\
\hline $\begin{array}{l}\text { 1. Učenici isključuju iz školskih aktivnosti } \\
\text { i druženja učenike koji se razlikuju od } \\
\text { Ostalih }\end{array}$ & 3,19 & 1,198 & 2,91 & 1,212 & 2,193 & 367 &, 029 \\
\hline $\begin{array}{l}\text { 2. Učenici ogovaraju jedni druge } \\
\text { 3. Nastavnici ismijavaju ili vrijeđaju neke } \\
\text { učenike }\end{array}$ & 4,01 & 1,131 & 3,59 & 1,203 & 3,396 & 361 &, 001 \\
\hline
\end{tabular}

Napomena: prikazane su samo tvrdnje na kojima je razlika statistički značajna

Pritom učenice češce od učenika navode da u njihovim školama učenici isključuju iz školskih aktivnosti i druženja učenike koji se razlikuju od ostalih, da učenici ogovaraju jedni druge te da nastavnici ismijavaju ili vrijeđaju neke učenike. Ovaj podatak indicira veću osjetljivost djevojčica od dječaka na pojavu navedenih oblika ponašanja učenika i nastavnika u školi.

Također nas je zanimalo postoji li statistički značajna razlika u učeničkoj procjeni školske klime s obzirom na školski uspjeh učenika. Razlike smo testirali pomoću 
analize varijance (one-way ANOVA). Školski uspjeh smo operacionalno iskazali kroz ocjene pri čemu su učenici bili kategorizirani u tri grupe: (1) koji su prošli s 4 i manje; (2) koji imaju ocjene od 4,1 do 4,7; i (3) koji imaju ocjene od 4,8 do 5 . Rezultati upućuju da između tri navedene grupe učenika postoji statistički značajna razlika samo u procjeni prisutnosti fizičkih sukoba u školi $[p=.005 ; \mathrm{F}(2,341)=$ 5.5; $\mathrm{p}=.005]$. Duncan-ov post-hoc test pokazuje da se statistički značajne razlike javljaju između učenika koji prolaze s 4 i manje $(M=3,42 ; S D=1,20)$ i učenika koji imaju najviše ocjene $(M=2,92 ; S D=1,04)$. Pritom učenici s najvišim uspjehom, za razliku od učenika s uspjehom nižim od 4, smatraju da su fizički sukobi između učenika u njihovoj školi rjeđi. Iako stvarne razlike u prosječnim vrijednostima učenika nisu velike, podaci omogućuju pretpostavku da učenici s najvišim školskim uspjehom imaju nešto pozitivniju sliku o školskom okruženju od onih učenika koji prolaze s 4 i nižim uspjehom.

Polazeći od pretpostavke da je za učeničku percepciju školske klime važno koliko su u školi izloženi nasilju provjerili smo i značajnosti razlika u učeničkim procjenama klime u školi s obzirom na učestalost doživljenog nasilja u školama. Rezultati testiranja značajnosti razlika su prikazani u Tablici 4.

Tablica 4

Razlike u učeničkoj percepciji klime u školi s obzirom na učestalost doživljenog nasilja u školi (agresivnost školske sredine)

\begin{tabular}{|c|c|c|c|c|c|c|c|}
\hline \multirow{2}{*}{ Tvrdnje } & \multicolumn{2}{|c|}{$\begin{array}{l}\text { Škole s manje } \\
\text { agresije }\end{array}$} & \multicolumn{2}{|c|}{$\begin{array}{l}\text { Škole s više } \\
\text { agresije }\end{array}$} & \multirow[b]{2}{*}{$\mathbf{t}$} & \multirow[b]{2}{*}{ df } & \multirow[b]{2}{*}{$\mathbf{p}$} \\
\hline & $\mathbf{M}$ & SD & $\mathbf{M}$ & SD & & & \\
\hline $\begin{array}{l}\text { 1. Učenici različitih stilova života se } \\
\text { međusobno dobro slažu }\end{array}$ & 3,30 & 1,022 & 3,07 & 1,149 & 2,074 & 368 &, 039 \\
\hline 2. Učenici vole biti u školi & 2,07 & 1,082 & 1,76 & 1,100 & 2,724 & 366 &, 007 \\
\hline 3. Učenici se fizički sukobljavaju & 2,97 & 1,089 & 3,41 & 1,225 & 3,619 & 360 &, 000 \\
\hline $\begin{array}{l}\text { 4. Nastavnici se odnose s poštovanjem i } \\
\text { uvažavanjem prema učenicima }\end{array}$ & 2,97 & 1,214 & 3,33 & 1,316 & 2,701 & 365 & ,007 \\
\hline
\end{tabular}

Napomena: prikazane su samo tvrdnje na kojima je razlika statistički značajna

Kako bi provjerili postoji li značajna razlika u učeničkoj percepciji školske klime obzirom na učestalost doživljenog nasilja u školi, škole smo grupirali u dvije kategorije ovisno o frekvenciji pojedinih oblika doživljenog nasilja: 1. škole s više nasilja ili agresije (škole u kojima su učenici u zadnjih mjesec dana doživjeli neku vrstu psihičkog ili fizičkog nasilja 3-4 puta te 5 i više od 5 puta) i 2. škole s manje agresije ili nasilja (škole u kojima su učenici u zadnjih mjesec dana doživjeli neku vrstu psihičkog ili fizičkog nasilja 1-2 puta ili ga uopće nisu doživjeli). Testiranjem značajnosti razlika utvrđeno je da između učenika iz škola u kojima je rjeđe nasilje i učenika iz škola u kojima učenici češće doživljavaju nasilje postoje statistički značajne razlike na četiri tvrdnje. Kao što smo očekivali, učenici iz škola s manje agresije 
imaju pozitivniji odnos prema školskoj klimi od učenika iz škola gdje učenici češće doživljavaju nasilje. Oni su naime, za razliku od učenika iz škola s više agresije, značajno češće odgovarali da se u njihovim školama učenici različitih stilova života međusobno dobro slažu i da u njihovim školama učenici vole biti u školi. Suprotno tome, učenici iz škola s više agresije značajno su češće nego učenici iz škola s manje agresije odgovarali da se u njihovim školama učenici fizički sukobljavaju. Interesantan je nalaz da učenici iz škola s manje agresije negativnije procjenjuju nastavnike od učenika iz škola s više agresije kada je riječ o nastavničkom poštovanju i uvažavanju učenika. Ovaj podatak da se nastavnici u školama u kojima učenici češće doživljavaju nasilje s više poštovanja odnose prema učenicima upućuje da problem nasilja u školama nije problem koji je povezan samo s odnosom nastavnik-učenik i koji mogu uspješno rješavati samo nastavnici ili škole. On je širi problem, jer u socijalizaciji djece pored škole značajnu ulogu imaju izvanškolski faktori kao što su individualne osobine učenika (Fraser, 1996.; Dake, Price i Telljohan, 2003.), socioekonomske i kulturne karakteristike obitelji te različiti kontekstualni faktori poput šire socijalne okoline (Khoury-Kassabri i sur., 2005.).

\section{2. Školska klima: perspektiva nastavnika i ravnatelja}

Osim učenika, u provedenom istraživanju sudjelovali su i ravnatelji i nastavnici u svrhu ispitivanja njihove percepcije školske klime vezane uz pojavljivanje i načine rješavanja sukoba u školi. U tekstu koji slijedi izdvojeni su isječci iz intervjua s ravnateljima i fokus grupa s nastavnicima vezano uz percepciju učestalosti sukoba i oblike sukoba u školama, te školske i izvanškolske čimbenike koji imaju negativan učinak u pogledu nasilja u školama.

\subsubsection{Sukobi u školama: tipovi i učestalost sukoba}

Kao što je na osnovi odgovora učenika bilo moguće grupirati škole ovisno o učestalosti doživljenog nasilja (škole s više nasilja i škole $s$ manje agresije ili nasilja), i odgovori nastavnika i ravnatelja sugeriraju kako postoje razlike između škola kada je riječ o pojavljivanju nasilja u školama. Pritom su uočljiva dva ekstrema: škola u kojoj su sukobi vrlo rijetki (a kada se dogode radi se uglavnom o verbalnim sukobima) i škola u kojoj su verbalni i fizički sukobi svakodnevni dio života u školi. Sljedeći isječci iz provedenih razgovora ilustriraju tu razliku:

Škola u kojoj su prema iskazima nastavnika i ravnatelja sukobi vrlo rijetki:

"Pa u našoj školi je dosta dobar odnos među učenicima, nema puno sukoba, i nisu jaki sukobi". (nastavnik/ca)

"tu je jedna onako više obiteljska atmosfera, $i$ mi gotovo da i nemamo nekih problema što se tiče agresije" (ravnatel/jica) 
"Nije ih bilo, $u$ dvije godine ih nije gotovo bilo. Bilo ih je na nekoj verbalnoj razini koji su se odmah rješavali". (ravnatel/jica)

Škola u kojoj su sukobi učestali:

"Pa naša škola je dosta specifična i zapravo sa sukobima se susrećemo svakodnevno, bilo da smo razrednici ili bilo da smo predmetni učitelji. Znači svaki dan, svaki sat nam stoji izazov prije početka sata ili za vrijeme sata riješiti određen sukob. Znači istovremeno odraditi svoj dio gradiva i riješiti, smiriti situaciju, riješiti sukob. Znači nema dana da nema nekog sukoba". (nastavnik/ca)

"Svaki dan, svaki sat..." (nastavnik/ca)

"sukobe imamo nažalost svakodnevno" (ravnatelj/ica)

U ostale tri škole u kojima su provedene fokus grupe s nastavnicima i intervjui s ravnateljima učestalost sukoba može se smjestiti na kontinuumu između spomenutih dviju škola. Jedna je škola na tom kontinuumu bliža školi u kojoj su sukobi rijetki: postoje primjeri sukoba ali "u granicama normale, da nemamo nikakve ekstreme" (ravnatel/jica). U toj su školi najčešći sukobi opisani kao kratkotrajne svađe, te prema iskazima nastavnika u školi nema raširenog "bullyinga". U drugim dvjema školama sukobi su nešto češći (radi se i o većim školama), iako ti sukobi nisu opisani kao fizički nasilni.

Razgovori s nastavnicima i ravnateljima ostavljaju dojam da su blaži oblici sukoba među učenicima sastavni dio života u školi (u nekim školama više, a u drugima manje), ali izuzev jedne škole nasilno je ponašanje u samim prostorima škole rijetko. No, takav općenit zaključak ne bi smio prikriti činjenicu da i u tim školama dolazi do nasilja među učenicima. Nastavnik/ca iz škole u kojoj su sukobi razmjerno rijetki navodi primjer učenika kojeg je verbalno zlostavljao drugi učenik, pri čemu žrtve takvih zlostavljanja opisuje kao mirnije i povučenije: "Oni nađu sebi žrtve, znaju djecu koja su povučenija, mirnija, koja neće vratiti istom mjerom, znači koji ce to podnositi dokle ide, dokle može podnijeti”. S druge strane, ravnatelj/ica iz iste škole upozorava da se, iako su fizički obračuni u njegovoj/njenoj školi rijetki, veliki broj "nasilničkih postupaka" dogodi na putu prema kući ili za vrijeme druženja učenika izvan škole.

Pored spominjanja slučajeva izravnog verbalnog i fizičkog nasilja, više je nastavnika i ravnatelja izrazilo zabrinutost vezano uz pojavu "cyber-bullyinga" odnosno verbalnog nasilja preko Facebook-a. U jednoj je školi na primjer ravnatelj/ica spomenuo/la učenika koji je formirao Facebook grupu za mržnju protiv drugog učenika, a u drugoj nastavnik/ca opisuje situaciju u kojoj "je jedan učenik djevojčicu preko Facebooka vrijeđao. Iznosio neke fotografije, a da ona to nije ni znala, jadna. Znači, postala je predmet rugla, na razini cijele škole $i$ šire”. 
Naposljetku, u stručnoj literaturi postoji konsenzus da su dječaci češće od djevojčica počinitelji i žrtve fizičkog nasilja (npr. Jimerson i sur., 2006.). Sukladno takvim nalazima, u ovom dijelu istraživanja više je sudionika fokus grupa i intervjua iznijelo svoj dojam da sukobi imaju i rodnu dimenziju pri čemu su dječaci skloniji fizičkom obračunavanju, dok su djevojčice sklonije verbalnom (potonje je bilo opisano od jednog nastavnika/ce kao "perfidnije", a od drugog/e kao "lukavije").

\subsubsection{Utjecaj školskih čimbenika}

Navedeni iskazi ravnatelja i nastavnika govore o učestalosti i oblicima sukoba i nasilja među učenicima. Kada je riječ o mogućim čimbenicima koji utječu na spomenute sukobe u školama među odgovorima ravnatelja i nastavnika posebno se ističu dva aspekta školskog okruženja: nedovoljna stručna osposobljenost nastavnika za rješavanje sukoba među učenicima, i ograničavajuće organizacijske karakteristike škole (vezane uz složenost formalnih procedura za rješavanje incidentnih situacija, nedovoljan broj stručnih suradnika i veličinu škole).

Komentirajući čimbenike koji negativno utječu na pojavljivanje nasilnih oblika ponašanja u školi više je nastavnika iz različitih škola istaklo da se ne osjećaju dovoljno kompetentnima rješavati sukobe u školama:

"Ja mislim da treba nam pomoć, kod takvih stvari, nismo mi baš ovaj educirani baš za te nekakve krizne situacije koje se dešavaju s tom djecom". (nastavnik/ca)

"Mi nismo dovolino educirani, mislim, koliko god sam se ja susretala u svojih 38 godina radnog staža sa takvim problemima, ali mislim da pravu edukaciju nemam, reagiram onako kako mislim da bi bilo najbolje" (nastavnik/ca)

"Većina nas sve intuitiuno dobro rjě̌ava." (nastavnik/ca)

"Mislim da često i nismo dovoljno stručni..." (nastavnik/ca)

Pored nedostatne educiranosti za rješavanje sukoba, ispitani nastavnici ukazuju također i na ograničavajuće organizacijske karakteristike škole. Posebno se naglašava složenost formalnih procedura za rješavanje incidentnih situacija odnosno poteškoće pri izricanju pedagoških mjera:

"Kaznama jako rijetko, rijetko ih primjenjujemo zaista, zato što nam je kao prvo upravni postupak gotovo nemoguc da se on izvede" (ravnatelj/ica)

"Vi ne možete više na kraju niti kaznu izreći djetetu jer to sve podliježe žalbama i ovom i onom i na kraju nema nikakve svrhe u tome" (nastaunik/ca) 
Vezano uz nemogućnost izricanja kazni učenicima, ispitani nastavnici iskazali su i zabrinutost vezanu uz autoritet nastavnika u rješavanju sukoba:

\begin{abstract}
"Ima još jedan problem u svemu tome općenito kod nas, recimo $u$ tom odgojno obrazovnom procesu gdje se autoritet nastavnika dosta srozao sa ovim raznim pravilnicima koji u principu dozvoljavaju pritužbe na nastavnike za svaku moguću sitnicu i roditelji si tu uzimaju puno prava, a u principu nemaju nikakve obveze $i$ na kraju se sve svodi na to da se kritizira nas i jednostavno se stvorila slika da i djeca mogu nas kritizirati jer oni nama već otvoreno prijete ma ići ću ja ravnatelju, ići ćemo mi na inspekciju, ići ćemo na ovo, tako da recimo dozvoljavaju si puno više nego sto su si nekada dozvoljavali..." (nastavnik/ca)
\end{abstract}

Pored nastavnika, kao važni za prevenciju i rješavanje sukoba u školama u razgovorima su spomenuti i stručni suradnici (pedagozi, psiholozi i logopedi). Nedostatak dovoljnog broja stručnih suradnika u školama postavljeno je kao problem u školi u kojoj su sukobi najučestaliji (škola u kojoj je jedan stručni suradnik), te najvećoj školi u kojoj je provedeno istraživanje (više od 900 učenika) gdje je ravnatelj napomenuo sljedeće: "S obzirom da je 958 učenika sad u školi da bi nam, trebao bi nam iskreno rečeno sigurno još jedan pedagog u kontra smjeni ili čak možda socijalni pedagog mada mi nemamo ovdje učenike sa dosjeima niti sa nekakvim kaznenim djelima, ali nekako bi se možda više bavio baš njihovim tim...tom socijalizacijom. Tad bi to išlo lakše $i$ bile bi obje smjene pokrivene ipak sa stručnim ljudima koji bi to mogli i automatski imali više vremena za njih."

Osim nedostatne educiranosti i autoriteta nastavnika, nedovoljnog broja stručnih suradnika te kompleksnosti propisanih procedura u rješavanju sukoba sugovornici su se složili i da veličina škole može utjecati na pojavnost sukoba među učenicima. Što se tiče veličine škola, manje škole povezane su, prema nastavnicima, i s manje sukoba. Sljedeći citati iz dviju škola ilustriraju taj zaključak:

\begin{abstract}
"Mala smo škola, ima nas tristo i nešto, dakle velika je šansa da se nekakvi sitni problemi neće nikome kroz prste promaknuti pa ce od toga nastati veći problem znači nas nema puno i tu je jedna onako više obiteljska atmosfera".

"Mala smo škola $i$ dosta dobro surađujemo timski i formiramo $i$ upucujemo, a onda od individue do individue".
\end{abstract}

Ovaj je zaključak komplementaran nalazima Khoury-Kassabari i sur. (2004.), prema kojima se vjerojatnost nasilnog ponašanja povećava s veličinom škole. 


\subsubsection{Utjecaj izvanškolskih čimbenika}

No iskazi nastavnika i ravnatelja također sugeriraju da se problem sukoba i nasilja u školama ne može odvojiti od izvanškolskih faktora rizika i to prvenstveno zdravstvenih poteškoća učenika i njihovih obiteljskih prilika. Kada govorimo o zdravstvenim poteškoćama, ADHD (deficit pažnje/hiperaktivni poremećaj) je spomenut kao uzrok nekih sukoba:

"Ako ima nekih to je više baš kod ove djece sa biperaktivnošcu i nažalost ta hiperaktivnost prelazi više ono u poremećaj u ponašanju $i$ ne-odgoj nego što je sama etimologija ADHD-a i tako. Teško se nositi s takvom djecom i njibovim roditeljima". (pedagog/inja)

"Među njima desetak možda sa ADHD-om i poremećajem, dakle, gdje u sebi ima jedan nemir $i$ onda su skloni sukobima, izazivati, pa su opasni i za svoje prijatelje u razredu, a i za sebe..." (nastavnik/ca)

Pored zdravstvenih poteškoća pojedinih učenika, odgovori nastavnika i ravnatelja upućuju da su veći uzrok sukoba u školi neskladni odnosi u obitelji:

"Puno učenika ima koji su pedagoški zapušteni, koji su zapravo prepušteni ulici i školi, i gdje je obitelj je zakazala". (ravnatelj/ica)

"95\% ako ne $i$ više tog nasilja upravo dolazi iz obitelji. Vezano uz tu obiteljsku atmosferu. Manje je to vezano uz socijalno ekonomske uvjete nego više je tu onu emociju obiteljsku, a nažalost koliko god ja nemam ništa protiv rastava - ali činjenica je da 95\% slučajeva ta velika nasilja i veliki problemi hiperaktivnost poremećaji u ponašanju dolaze iz raspadnutih obitelji jer najčešce - to je uvijek traumatično". (pedagog/inja)

Na tragu gore prepoznate važnosti obiteljske situacije učenika u provedenim razgovorima s nastavnicima i ravnateljima ukazano je i na važnost roditeljske uključenosti u rad škole. U tom smislu navode se primjeri roditelja koji su uključeni u rad škole i s kojima škola ima partnerske odnose, te takve odnose povezuju s pozitivnim ponašanjem učenika:

"I sa roditeljima se puno radi $i$ na roditeljskim sastancima $i$ na informativnom razgovoru i potiče se odgovorno roditeljstvo i mislim da to rezultira onda i odgovornim ponašanjem učenika". (ravnatelj/ica)

S druge strane ukazuje se i na posljedice loše komunikacije između škole i roditelja:

"Ako vi ne možete uspostaviti nekakav dobar kontakt s roditeljem da onda ne možemo zapravo niti djelovati ni na dijete". (nastavnik/ca) 


\begin{abstract}
"Ima različitih iskustava od roditelja koji su totalno zatvoreni za ikakvu komunikaciju, za ikakvu suradnju, do roditelja koji su otvoreni, koji razumiju svoje dijete, razumiju situaciju, razumiju i ambijent, klimu školsku, s kojima se može nešto i tu ima uglavnom nekakvih pomaka. I roditelja koji definitiono kritiziraju školu, učitelja, djecu, svi su drugi krivi, njibovo dijete nije”. (nastavnik/ca)
\end{abstract}

Gore navedeni aspekti (obiteljski odnosi i odnos roditelja prema školi, zdravstvene poteškoće učenika) predstavljeni su kao uzrok mnogih sukoba u školama koje škole ne mogu rješavati: "Mi u školama rješavamo posljedice $i$ saniramo vatru, gasimo vatru...mi zapravo rješavamo samo posljedice a uzrok, gdje je, odakle je, dubinu, i način to je vrlo..." Radi se o čimbenicima koji su prepoznati i u drugim istraživanjima kao što je to Fraser (1996.).

Pored gore navedenih izvanškolskih čimbenika koji utječu na pojavnost nasilja u školi u razgovorima s nastavnicima i ravnateljima spomenuti su još širi društveni kontekst i posebno utjecaj medija.

\title{
5. Zaključna razmatranja
}

Uvodno je istaknuto kako smo problematici nasilja u školi pristupili iz ekološko-razvojne perspektive. Pri razmatranju ovoga koncepta istaknuta je važnost školskog okruženja za pozitivnu socijalnu participaciju i razvoj socijalnih vještina učenika i kroz to za (ne)pojavljivanje nasilnih obrazaca ponašanja u školi. Pritom su posebno apostrofirani pojedini aspekti školske klime, prvenstveno odnosi među učenicima i odnosi između učenika i nastavnika.

Kada je riječ o odnosima među učenicima iz učeničke perspektive, dobiveni odgovori indiciraju da ti odnosi nisu jednoznačni tj. da prisutnost različitih oblika sukoba ne isključuje suradničke odnose. Iz podataka je također vidljivo da među učenicima prevladavaju verbalni sukobi, točnije ogovaranje, ismijavanje ili međusobno vrijeđanje. Ipak, zaključno treba istaknuti podatak da pritom $42 \%$ ispitanih učenika navodi da se učenici u njihovim školama i fizički sukobljavaju što upozorava da je nasilje u školama ozbiljan problem školskog života. S druge strane gotovo dvije trećine učenika istodobno procjenjuje da se učenici prijateljski i suradnički odnose jedni prema drugima. Navedeni obrasci ponašanja učenika upućuju na supostojanje konfliktnih i suradničkih aspekata školskog okruženja što svjedoči i faktorska analiza kojom su ovi obrasci izlučeni kao dvije zasebne dimenzije (faktori) školske klime. Podaci o značajnosti razlika u percepciji učenika s obzirom na njihov spol, školski uspjeh i učestalost doživljenjog nasilja u školi pokazuju da je u razmatranju školske klime potrebno voditi računa i o specifičnostima pojedinih skupina učenika. Točnije, utvrđene razlike indiciraju da su djevojčice "osjetljivije" od dječaka na pojavu nasilja u školi te da učenici s najvišim ocjenama nešto pozitivnije procjenjuju školsko okruženje od ostalih učenika. Za prevenciju nasilja u školama instruktivan je podatak koji potvrđuje da učenici u školama s manje agresije 
imaju pozitivniji stav prema školskom okruženju od učenika iz škola s učestalijim nasilnim ponašanjem. Navedeni rezultati oslikavaju kompleksnost i promjenjivost odnosa među učenicima, što je u skladu s pretpostavkom da se ti odnosi oblikuju na više interakcijskih razina (Holtappels i Meier, 2000.).

Kao i u slučaju odnosa među učenicima i učenička percepcija odnosa na relaciji nastavnik - učenici također sadrži proturječne elemente. Potonji se ogledaju u činjenici da učenici nastavnike s jedne strane percipiraju kao osobe od kojih se može dobiti podrška u rješavanju sukoba, no da istodobno dovode u pitanje njihovo poštovanje i uvažavanje učenika i posebno njihovo poimanje pravednosti u odnosima s učenicima. Manji dio učenika štoviše smatra da nastavnici ismijavaju i vrijeđaju učenike, što kao i prethodno, može ukazivati na problem nedovoljne osposobljenosti nastavnika za rješavanje sukoba među učenicima (usp. Pregrad, 2011.). Ukupno uzevši, odgovori učenika o ispitivanim aspektima školske klime ukazuju na višeznačno i kompleksno socijalizacijsko okruženje u školi koje osim pozitivnih elemenata, sadrži i elemente koji mogu negativno utjecati na interakcijske obrasce i socijalni razvoj učenika.

Iz ravnateljske i nastavničke perspektive blaži oblici sukoba među učenicima čine se kao sastavni dio školske svakodnevice, iako oblici i učestalost nasilja variraju od škole do škole. Kada je riječ o oblicima nasilja među učenicima, pored direktnog fizičkog i verbalnog nasilja više je nastavnika i ravnatelja kao razmjerno novi oblik nasilja navelo pojavu "cyber-bullyinga" ili nasilja na internetu. Pored toga navedena je i rodna dimenzija sukoba koja je prisutna i u učeničkoj percepciji školske klime, a odnosi se na nalaz da su dječaci skloniji fizičkom obračunavanju, dok su djevojčice sklonije verbalnom. No razgovori s nastavnicima i ravnateljima ukazuju i na manje izravne, no jednako važne, čimbenike socijalnog okruženja u školi. Kao čimbenici koji mogu otežavati konstruktivno rješavanje sukoba u školama tu se prvenstveno pojavljuju nedovoljna stručna osposobljenost nastavnika, i vezano uz to, prisutna sklonost da se problematika nasilja u školi povezuje prije s deficitom raspoloživog disciplinskog instrumentarija (kompleksnost procedura za izricanje disciplinskih mjera) i "srozanim autoritetom" nastavnika, nego s propitivanjem vrijednosno-normativnih, interakcijskih i relacijskih aspekata školskog okruženja. S druge strane, važno je također istaknuti da su u provedenim razgovorima nastavnici i ravnatelji bili jedinstveni u stavu da se promatrani aspekti školske klime vezani uz sukobe u školi ne mogu odvojiti od izvanškolskih čimbenika, prvenstveno zdravstvenih poteškoća učenika (npr. ADHD) i njihovih obiteljskih prilika. Pritom je posebno ukazano na negativan utjecaj nesređenih obiteljskih odnosa koji, s jedne strane izravno utječu na ponašanje učenika u školi, a s druge mogu otežati ili čak onemogućiti komunikaciju između škole i roditelja. Opisani odgovori nastavnika i ravnatelja na tragu su prije spomenute teze o školskoj klimi kao kompleksnom i višeznačnom interakcijskom okruženju koje s različitih aspekata može utjecati na pojavljivanje i načine rješavanja sukoba u školi.

Na kraju valja spomenuti neka ograničenja i moguće implikacije navedenih aspekata nasilja u školi za buduća istraživanja. U istraživanju nisu ispitivane veze 
između pojedinih elemenata školske klime i nasilnih oblika ponašanja u školi kao ni njihovo uzajamno djelovanje s drugim kontekstualnim čimbenicima (školskim ili izvanškolskim), što bi između ostalog trebalo ispitati u budućim istraživanjima. Pritom bi primjerice, trebalo istražiti koliko socio-ekonomski status učenika, školska klima i obilježja obitelji doprinose objašnjenjima nasilja u školi i pojačavaju li se ovi faktori međusobno ili prije djeluju nezavisno jedan od drugih. Za razumijevanje nasilja u školi također je važno utvrditi koje su osnovne karakteristike proaktivno angažiranih nastavnika i ravnatelja i na koji način oni mogu utjecati na razvoj socijalnih odnosa u školi i/ili jačanje povjerenja na relaciji škola - roditelji. Smatramo da ova i slična pitanja čine moguće smjernice za buduća istraživanja problematike nasilja u školi, i koristan okvir za intervencije zasnovane na znanstvenim analizama.

\section{Literatura}

Baranović, B.; Domović, V. i Štibrić, M. (2006). O aspektima školske klime u osnovnim školama u Hrvatskoj. Sociologija sela, 44 (4):485-502.

Baker, J. A. (1998). Are We Missing the Forest for the Trees? Considering the Social Context of School Violence. Journal of School Psychology, 36 (1):29-44.

Bošnjak, B. (1997). Drugo lice škole. Istraživanje razredno-nastavnog ozračja. Zagreb: Alinea.

Bouillet, D.; Uzelac, S. i Kapac, V. (2005). Iskaz razrednika o nasilničkom ponašanju u hrvatskim školama. Napredak, 146 (2):170-182.

Buljan Flander, G.; Durman Marijanović, Z. i Ćorić Špoljar, R. (2007). Pojava nasilja među djecom s obzirom na spol, dob i prihvaćenost/odbačenost u školi. Društvena istraživanja, 16 (1-2):157-174.

Dahlberg, L. L; Toal, S. B.; Swahn, M.; Behrens, C. B. (2005). Measuring Violence-Related Attitudes, Behaviors, and Influences Among Youths: A Compendium of Assessment Tools, 2nd ed. Atlanta, GA: Centers for Disease Control and Prevention, National Center for Injury Prevention and Control.

Dake, J. A.; Price, J. H. i Telljohan, S. K. (2003). The Nature and Extent of Bullying at School. Journal of School Health, 73 (5):173-180.

Domović, V. (2003). Školsko ozračje i učinkovitost škole. Jastrebarsko: Naklada Slap.

Fraser, M. W. (1996). Aggressive Behavior in Childhood and Early Adolescence: An Ecological-Developmental Perspective on Youth Violence. Social Work, 41 (4):347-361.

Holtappels, H. G. i Meier, U. (2000). Violence in Schools. European Education, 32 (1):66-79.

Jimerson, S.; Furlong, M. J.; Nickerson, A. i Mayer, M. (ur.) (2006). Handbook of School Violence and School Safety. London: Routledge.

Jutarnji list (2011). Zlostavljana djevojčica: Prišla mi je s leđa i udarila me u glavu. Pala sam, a ona me nastavila šutati. Jutarnji list, 20. 10. 2011.

Karlović, A. (ur.) (2006). Nasilje među djecom. Zagreb: Poliklinika za zaštitu djece grada Zagreba. (http://www.poliklinika-djeca.hr/publikacije/nasilje-medu-djecom-2/)

Khoury-Kassabri, M.; Benbenishty, R.; Astor, R. A. i Zeira, A. (2004). The Contributions of Community, Family, and School Variables to Student Victimization. American Journal of Community Psychology, 34 (3/4):187-204.

Khoury-Kassabri, M.; Benbenishty, R. i Astor, R. A. (2005). The Effects of School Climate, Socioeconomics, and Cultural Factors on Student Victimization in Israel. Social Work Research, 29 (3):165-180. 
Lindstrom Johnson, S. (2009). Improving the School Enviroment to Reduce School Violence: A Review of the Literature. Journal of School Health, 79 (10):451-465.

Peterson, R. L. i Skiba, R. (2001). Creating School Climates That Prevent School Violence. The Social Studies, July/August: 167-175.

Pregrad, J. (2011). Priručnik: Program prevencije vršnjačkog nasilja "Za sigurno i poticajno okruženje u školama”. Zagreb: Ured UNICEF-a za Hrvatsku.

Šavora, B. (2003). Agresija (nasilje) u svakodnevici srednjoškolaca. Napredak, 144 (4):474485 .

Tableman, B. (2004). School Climate and Learning, Best practice briefs. Michigan State University. Pregledano 2. 7. 2011. (http://outreach.msu.edu/bpriefs/issues/brief31.pdf). Večernji list (2011). Škola pokušala zataškati da je pretučena kći Nikše Kaleba. Večernji list, 5. 11. 2011.

Zloković, J i Bilić, V. (2006). Emocionalno i tjelesno nasilje nad djecom u školi. Napredak, 147 (1):5-16. 


\author{
Saša Puzić \\ Institute for Social Research in Zagreb \\ puzic@idi.hr \\ Branislava Baranović \\ Institute for Social Research in Zagreb \\ baranov@idi.hr \\ Karin Doolan \\ Department of Sociology, University of Zadar \\ kdoolan@unizd.hr
}

\title{
School Climate and Conflicts in School
}

\begin{abstract}
The article reports on empirical research which examined pupils', teachers' and principals' perceptions of school climate related to conflicts among pupils. Pupil conflicts were explored from an ecological-developmental perspective, including a sample of 370 pupils in their final year of compulsory schooling across 10 primary schools in Zagreb, 29 teachers and 5 principals. The research employed a mixed methods design: questionnaires administered to pupils, focus groups with teachers and interviews with principals.
\end{abstract}

The results show that verbal conflicts between pupils prevail, but a substantial number of pupils also reported physical conflicts among pupils. Pupil responses indicated that both conflictual and cooperative relations exist in schools. In relation to teacher-pupil contact, pupils reported they perceived teachers as people they could rely on for support in conflict resolution, but at the same time expressed lower estimates for teachers' respect for pupils. The research identified girls in comparison to boys as "more sensitive" to violence in schools, as well as a more positive perception of the school enviroment by pupils with higher grades and pupils who less often experienced violence in schools.

Teachers and principals reported that milder forms of conflict among pupils were part of everyday school life. Several teachers and principals expressed their concern with the phenomenon of "cyber-bullying", i.e. verbal violence over Facebook. The insufficient professional development of teachers in conflict resolution, restricted organisational characteristics of schools, pupils' health problems and problems in the family environment have been identified as factors which negatively affect school climate and the incidence of conflicts.

Key words: school climate, ecological-developmental perspective, conflict and violence in schools, relations between pupils, pupil-teacher relations, pupil perspective, teacher and principal perspective 